\title{
Mitigating the Water Footprint of Export Cut Flowers from the Lake Naivasha Basin, Kenya
}

\author{
M. M. Mekonnen • A. Y. Hoekstra • R. Becht
}

Received: 20 December 2010 / Accepted: 21 June 2012 /

Published online: 14 July 2012

C The Author(s) 2012. This article is published with open access at Springerlink.com

\begin{abstract}
Kenya's cut-flower industry has been praised as an economic success as it contributed an annual average of US\$ 141 million foreign exchange (7\% of Kenyan export value) over the period 1996-2005 and about US\$ 352 million in 2005 alone. The industry also provides employment, income and infrastructure such as schools and hospitals for a large population around Lake Naivasha. On the other hand, the commercial farms have been blamed for causing a drop in the lake level, polluting the lake and for possibly affecting the lake's biodiversity. The objective of this study is to quantify the water footprint within the Lake Naivasha Basin related to cut flowers and analyse the possibility to mitigate this footprint by involving cut-flower traders, retailers and consumers overseas. The water footprint of one rose flower is estimated to be 7-13 litres. The total virtual water export related to export of cut flowers from the Lake Naivasha Basin was $16 \mathrm{Mm}^{3} / \mathrm{yr}$ during the period 1996-2005 (22\% green water; $45 \%$ blue water; $33 \%$ grey water). Our findings show that, although the decline in the lake level can be attributed mainly to the commercial farms around the lake, both the commercial farms and the smallholder farms in the upper catchment are responsible for the lake pollution due to nutrient load. The observed decline in the lake level and deterioration of the lake's biodiversity calls for sustainable management of the basin through pricing water at its full cost and other regulatory measures. Pricing water at full marginal cost is important, but the conditions in Kenya are unlikely to result in serious steps to full-cost pricing, since many farmers resist even modest water price increases and government is lacking means of enforcement. We propose an alternative in this study that can be implemented with a focus on sustainable water use in flower farming around Lake Naivasha alone. The proposal involves a water-sustainability agreement between major agents along the cut-flower supply chain and includes a premium to the final product at the retailer end of the supply chain. Such a 'water sustainability premium' will raise awareness among flower consumers and - when channelled back to the farmers - facilitate the flower farms to install the necessary equipment and implement the right measures to use water in a sustainable manner. The collected premiums will generate a fund that can be used for financing measures to reduce the water footprint and to improve watershed management.
\end{abstract}

M. M. Mekonnen $(\bowtie) \cdot$ A. Y. Hoekstra $\cdot$ R. Becht

Twente Water Centre, University of Twente, Enschede, The Netherlands

e-mail: m.m.mekonnen@ctw.utwente.nl 
Keywords Cut flower export - Lake Naivasha - Water footprint · Water sustainability agreement

\section{Introduction}

Lake Naivasha is situated $80 \mathrm{~km}$ northwest of Nairobi in the Rift Valley of Kenya ( $0045^{\prime} \mathrm{S}$, $36020^{\prime} \mathrm{E}$ ). It is Kenya's second largest freshwater lake without surface outlet and the natural fluctuation in water levels over the last 100 years has been in excess of 12 meters (Mavuti and Harper 2005). The lake remains fresh due to a significant outflow of groundwater. The lake has international value as a Ramsar wetland. In the last three decades, the area around Lake Naivasha has grown to become the main site of Kenya's horticultural industry (mainly cut flower), which is the third most important foreign exchange earner after tea and tourism. Since the late 1990s, the flower farms started to expand at a faster rate (Becht et al. 2005). The total irrigated commercial farm area around Lake Naivasha is about 4,450 ha. Cut flowers account for about $43 \%$ of the irrigated area, followed by vegetables with $41 \%$ and fodder with $15 \%$ (Musota 2008).

The major flower varieties grown and exported from Kenya are roses, carnation, alstroemeria, lisianthus, statice and cut foliage. Rose flower dominates the export market, accounting for over $70 \%$ of the export volume (HCDA 2007). The main flower growing regions are Lake Naivasha, Thika and Kiambu/Limuru (EPZA 2005b), with Lake Naivasha accounting for about $95 \%$ of the cultivated area.

The lake has attracted attention and concerns from both national and international organisations. The main stakeholders have shown concern about the health of the lake, mainly related to the decline of the lake level, deterioration of the water quality and reduction of biodiversity. Some of the main stakeholders active around the lake are the Lake Naivasha Riparian Association (LNRA), the Lake Naivasha Growers Group (LNGG) and Kenya Wildlife Services (KWS). The concerns have led to the development of a Management Plan in 1996 by the main stakeholders (Becht et al. 2005). Around that time, the Lake Naivasha Management Implementation Committee (LNMIC) was formed to execute the management plan. The plan was officially approved by the Government of Kenya in 1997.

Kenya's water sector reform has gone a long way before the adoption of the Water Act in 2002. The first water sector reform in Kenya was in 1974, when the first National Water Master Plan was launched (Kisima 2007). The publication of the 'Sessional Paper No. 1 of 1999 on National Policy on Water Resources Management and Development' led to a new momentum (Owuor and Foeken 2009). The Water Act 2002 has introduced comprehensive and, in many instances, radical changes to the legal framework for the management of the water sector in Kenya (Mumma 2005). The National Water Resources Management Strategy document specifies ten 'specific objectives'. Among these are (Owuor and Foeken 2009): (a) manage the water demand in a sustainable way, and (b) water pricing that recognizes water as an economic good.

Kenyan government considers water as both a social and economic good, to be available for all Kenyans and at a price reflecting its market value. This principle is reflected in the different water sector strategies and water resource management rules. Among the strategies pursued are demand management, the re-allocation of water to where it has high return and efficient allocation of water through appropriate pricing.

As water is becoming an increasingly scarce resource, full-cost pricing of water is recognized as an effective tool for its management. The need to have full-cost pricing of water has received worldwide acknowledgement since the International Conference on Water and the Environment held in Dublin, 1992. Agenda 21 of the United Nations (UN 
1992) further supported the internalization of environmental costs and the use of economic instruments for rational use of water resources. The World Water Commission (2000) stated that 'the single most immediate and important measure that we can recommend is the systematic adoption of full-cost pricing for water services'. Hoekstra (2011) and Rogers et al. (2002) argue that sustainable and efficient use of water requires full-cost pricing of water use, including all cost components: the operation and maintenance costs, capital costs, opportunity costs, scarcity rent and externality costs of water use.

However, there are few successful examples of implemented full-cost pricing of water (Cornish et al. 2004; Rosegrant and Cline 2002; Dinar and Subramanian 1998). In most OECD countries, let alone in developing countries, the implementation of water pricing policies has been slow and uneven (Molle and Berkoff 2007; Perry 2003; Rosergrant and Cline, 2002). The World Bank (2004) acknowledged the complexity of water pricing reform (both in theory and practice) for irrigation. It further advocates a 'pragmatic but principled' approach that respects principles of efficiency, equity and sustainability while recognizing that water resources management is intensely political and that reform requires the articulation of prioritized, sequenced, practical and patient interventions.

The objective of the present study is to quantify the water footprint within the Lake Naivasha Basin related to horticulture, in particular the flower farms, and to analyse the possibility to mitigate this footprint by involving cut-flower traders, retailers and consumers overseas. In addition, we will explore the idea of a voluntary sustainable-flower agreement between major agents along the flower supply-chain that involves a watersustainability premium to be paid by the consumers in the countries importing flowers from Kenya.

\section{Method}

The green, blue and grey components of the water footprint of products were calculated following the method of Hoekstra et al. (2011). The green water footprint refers to the volume of rainwater consumed; the blue water footprint refers to the volume of surface and groundwater consumed; the grey water footprint is the volume of freshwater that is required to assimilate the load of pollutants based on the existing water quality standards (Hoekstra and Chapagain 2007, 2008). The water footprint of a crop $\left(\mathrm{m}^{3} / \mathrm{ton}\right)$ is calculated as the ratio of the volume of water $\left(\mathrm{m}^{3} / \mathrm{ha}\right)$ consumed or polluted during the entire period of crop growth to the corresponding crop yield (ton/ha). Water consumption has two components: green and blue water consumption. The grey component of the water footprint of crops $\left(\mathrm{m}^{3} / \mathrm{ton}\right)$ is calculated by dividing the amount of nitrogen that leaches to the water system $(\mathrm{kg} / \mathrm{ha})$ by the maximum acceptable concentration of nitrogen $\left(\mathrm{kg} / \mathrm{m}^{3}\right)$ and the crop yield (ton/ha).

The crop water requirements, effective rainfall and irrigation requirement for the different vegetables and cut flower grown around Lake Naivasha were estimated using CROPWAT (FAO 2007a). The calculation was done using climatic data obtained from CLIMWAT (FAO $2007 b)$ for Naivasha climate station $\left(0.43^{\circ} \mathrm{S}\right.$ and $\left.36.26^{\circ} \mathrm{E}\right)$. The cut flowers are perennial crops and vegetables are grown all over the year with multi-cropping. Therefore, the blue water footprint for vegetables such as cabbages, onions and tomato was calculated by running CROPWAT for each planting cycle.

For the other 22 crops grown in the upper catchment of the Lake Naivasha Basin, a crop water use model (Mekonnen and Hoekstra 2010) was used to carry out a daily soil water balance and calculate the green, blue and grey water footprint at 5 by 5 arc minute spatial resolution. The model was run for the whole of Kenya and later the Lake Naivasha Basin 
raster map was used as a mask to extract basin-specific data for each of the 22 crops on: production (ton/yr), rain-fed and irrigated area (ha/yr), and crop water use $\left(\mathrm{m}^{3} / \mathrm{ha}\right)$.

Virtual water exports $\left(\mathrm{m}^{3} / \mathrm{yr}\right)$ related to exports of cut flowers and vegetables were calculated by multiplying the trade volumes (tons/yr) by their respective water footprint in Kenya ( $\mathrm{m}^{3} /$ ton).

\section{Data}

The Lake Naivasha Basin is schematised here into two parts: the upper catchment with smallholder farms and the area around Lake Naivasha with big farms producing for export. Grid data on type and size of farms around Lake Naivasha was obtained from the ITC Naivasha database (Becht 2007). For crops grown in the upper catchment, the crop growing areas with 5 arc minute grid cell resolution (which is equivalent to $9.3 \times 9.3 \mathrm{~km}^{2}$ around Naivasha) were obtained from Monfreda et al. (2008). The grid crop area data was aggregated to a national level and compared with and scaled to fit national average crop harvest area for the period 1996-2005 obtained from FAOSTAT (FAO 2007c).

The cut-flower production for the period 1996-2005 around Lake Naivasha was calculated from the export data assuming that $95 \%$ of the cut-flower production is exported.

The crop parameters (crop coefficients and start and length of cropping seasons) for the different vegetables were taken from Chapagain and Hoekstra (2004). For cut flowers, the crop parameters were adopted from Orr and Chapagain (2006). The evapotranspiration in greenhouse conditions is assumed to be $65 \%$ of the outdoor condition as suggested by various authors (Mpusia 2006; Baille et al. 1994; Orgaz et al. 2005). The average water footprint of cut flowers was estimated based on the weighted average of indoor and outdoor farm areas. About $62 \%$ of the cut flowers around Lake Naivasha are grown in greenhouses (Musota 2008). Table 1 gives the irrigated area and fertilizer application rate for irrigated crops around Lake Naivasha. A leaching-runoff fraction of $10 \%$ was assumed, following Hoekstra and Chapagain (2008).

Grid-based soil moisture data of total available water capacity (TAWC) at 5 arc minute resolution was taken from ISRIC-WISE (Batjes 2006). An average value of TAWC of the five soil layers was used in the model. The main data source for nitrogen fertilizer application rate per crop for the upper catchment was FAO (2009).

Data on irrigated area per crop was obtained mainly from the AQUASTAT country profile database (FAO 2005) and Portmann et al. (2008). For rice, data on irrigated area was obtained from EPZA (2005a). The country level irrigated area data is distributed to grid cells according to area equipped for irrigation (AEI). The Global Map of Irrigation Areas version 4.0.1 (Siebert et al. 2007) with spatial resolution of 5 arc minute was used to define the area equipped for irrigation for each grid cell. The distribution was done proportional to the harvested area of each cropped grid cell. For cases where there is no AEI data or the AEI does not match with the irrigated area data, the irrigation area data is distributed proportional to the harvest area of each cropped grid cell.

Average monthly reference evapotranspiration data at 10 arc minute resolution were obtained from FAO (2008). The $10 \mathrm{~min}$ data was converted to 5 arc minute resolution by assigning the $10 \mathrm{~min}$ data to each of the four $5 \mathrm{~min}$ grid cells. Following the CROPWAT approach, the monthly average data was converted to daily values by curve fitting to the monthly average through polynomial interpolation.

Monthly values for precipitation, wet days, minimum and maximum temperature with a spatial resolution of 30 arc minute were obtained from CRU through CGIAR-CSI GeoPortal 
Table 1 Irrigated crops around Lake Naivasha, Year 2006

\begin{tabular}{|c|c|c|c|c|c|}
\hline \multirow[t]{2}{*}{ Crop } & \multicolumn{2}{|c|}{  } & \multicolumn{3}{|c|}{ Fertilizer application rate $(\mathrm{kg} / \mathrm{ha})^{2}$} \\
\hline & Area (ha) & $\%$ & $\mathrm{~N}$ & $\mathrm{P}_{2} \mathrm{O}_{5}$ & $\mathrm{~K}_{2} \mathrm{O}$ \\
\hline Total flowers & 1911 & 42.8 & 325 & 145 & 303 \\
\hline Roses & 1028 & 23.0 & 325 & 145 & 303 \\
\hline Roses \& carnations & 730 & 16.3 & 325 & 145 & 303 \\
\hline Roses, hypercium & 21 & 0.5 & 325 & 145 & 303 \\
\hline Other flowers & 132 & 3.0 & 325 & 145 & 303 \\
\hline Total vegetables & 1824 & 40.8 & 185 & 179 & 55 \\
\hline Babycorn & 205 & 4.6 & 41 & 113 & 0 \\
\hline Babycorn \& beans & 143 & 3.2 & 252 & 141 & 81 \\
\hline Babycorn, beans \& cabbage & 169 & 3.8 & 235 & 141 & 81 \\
\hline Babycorn, beans \& onions & 906 & 20.3 & 244 & 244 & 81 \\
\hline Beans/tomatoes & 21 & 0.5 & 235 & 141 & 81 \\
\hline Cabbage & 374 & 8.4 & 68 & 94 & 0 \\
\hline Cabbage \& beans & 6 & 0.1 & 235 & 141 & 81 \\
\hline Total fodder & 665 & 14.9 & 68 & 94 & 0 \\
\hline Grass & 286 & 6.4 & 68 & 94 & 0 \\
\hline Grass \& lucerne & 40 & 0.9 & 68 & 94 & 0 \\
\hline Lucerne & 163 & 3.7 & 68 & 94 & 0 \\
\hline Lucerne, babycorn, beans & 176 & 3.9 & 68 & 94 & 0 \\
\hline Macadamia & 50 & 1.1 & 68 & 94 & 0 \\
\hline Eucalyptus & 17 & 0.4 & & & \\
\hline Total & 4467 & 100.0 & & & \\
\hline
\end{tabular}

${ }^{1}$ Musota (2008), ITC Naivasha database (Becht 2007)

${ }^{2}$ Tiruneh (2004), Xu (1999), Ariga et al. (2006)

(Mitchell and Jones 2005). The 30 arc minute data were assigned to each of the thirty-six 5 arc minute grid cells contained in the 30 arc minute grid cell. Daily precipitation values were generated from these monthly average values using the CRU-dGen daily weather generator model (Schuol and Abbaspour 2007).

Data on trade in cut flowers and vegetable products in the period 1996-2005 have been taken from the SITA (Statistics for International Trade Analysis) database available from the International Trade Centre (ITC 2007).

\section{Water Use within the Lake Naivasha Basin Related to Cut-Flower Production}

\subsection{The Water Footprint within the Lake Naivasha Basin Related to Crop Production}

The water footprint related to crop production in the Lake Naivasha Basin is presented in Table 2. Two groups of crops are shown: fully irrigated crops grown by commercial farms mainly for export and concentrated around Lake Naivasha, and other crops which are cultivated by small farmers in the upper catchment. The total water footprint related to crop production sums up to $102 \mathrm{Mm}^{3} / \mathrm{yr}$. About $68.7 \%$ of the water footprint is related to green 
Table 2 Water footprint of crops grown in the Lake Naivasha Basin, 1996-2005

\begin{tabular}{|c|c|c|c|c|c|c|}
\hline \multirow[t]{2}{*}{ Land use } & \multicolumn{2}{|c|}{ Area cultivated* } & \multicolumn{4}{|c|}{ Water footprint $\left(1,000 \mathrm{~m}^{3} / \mathrm{yr}\right)$} \\
\hline & Area (ha) & Irrigated $(\%)$ & Green & Blue & Grey & Total \\
\hline \multicolumn{7}{|l|}{ Commercial farms around the lake } \\
\hline Total flower & 1712 & 100 & 3640 & 7576 & 5627 & 16842 \\
\hline Flowers open & 652 & 100 & 3640 & 1770 & 2122 & 7532 \\
\hline Flowers greenhouse & 1076 & 100 & 0 & 5805 & 3504 & 9310 \\
\hline Vegetables & 1885 & 100 & 7887 & 7375 & 1834 & 17097 \\
\hline Fodder & 665 & 100 & 3716 & 3194 & 452 & 7362 \\
\hline Macadamia & 50 & 100 & 278 & 303 & 34 & 615 \\
\hline Total of commercial farms & 4327 & 100 & 15521 & 18448 & 7947 & 41916 \\
\hline \multicolumn{7}{|c|}{ Farms in the upper catchment of the basin } \\
\hline Cereals & 12125 & $1 \%$ & 34776 & 82 & 1655 & 36513 \\
\hline Pulses & 2199 & $0 \%$ & 3958 & 0 & 2673 & 6631 \\
\hline Others & 3813 & $7 \%$ & 15876 & 382 & 809 & 17067 \\
\hline Total of upper catchment farms & 18137 & $2 \%$ & 54609 & 465 & 5137 & 60211 \\
\hline Grand total & 22465 & $21 \%$ & 70130 & 18913 & 13084 & 102127 \\
\hline
\end{tabular}

*Areas of the commercial farms based on 2006-data from Musota (2008); Becht (2007), adjusted for 1996-2005

water, $18.5 \%$ blue water and $12.8 \%$ grey water. The commercial crops contribute $41 \%$ to the total water footprint related to crop production. About $98 \%\left(18.4 \mathrm{Mm}^{3} / \mathrm{yr}\right)$ of the blue water footprint and about $61 \%$ of the grey water footprint in the catchment area can be attributed to the commercial farms around the lake.

In addition to the irrigated farms which are found around Lake Naivasha, the basin is used mainly for cattle and game rangeland. Smallholder farmers growing mainly maize, vegetables and other crops occupy areas which receive high rainfall. There are about 18,000 ha of farm land in the upper catchment of which only $2 \%$ is irrigated. The average water footprint related to the production of these crops over the period 1996-2005 was about $60 \mathrm{Mm}^{3} / \mathrm{yr}$ ( $90.7 \%$ green water, $0.8 \%$ blue water; $8.5 \%$ grey water).

Cut flowers take a large share of the water footprint related to crop production around Lake Naivasha, contributing about $98 \%$ and $41 \%$ to the blue and total water footprint respectively. The production water footprint related to cut flowers is about $16.8 \mathrm{Mm}^{3} / \mathrm{yr}$ (Table 2). Flowers grown in greenhouses are assumed to be fully supplied with irrigation water, while flowers cultivated in the open field get both rainwater and irrigation water. For flowers grown in the open field the blue water component is only $24 \%$ of the total water footprint, while for flowers grown in greenhouses the evaporative water consumption is met fully from irrigation water (Table 3). The average water footprint of cut flowers grown around Lake Naivasha is $367 \mathrm{~m}^{3} /$ ton. About $45 \%\left(165 \mathrm{~m}^{3} /\right.$ ton $)$ of this water footprint refers to blue water, $22 \%\left(79 \mathrm{~m}^{3} /\right.$ ton $)$ to green water and $33 \%\left(123 \mathrm{~m}^{3} /\right.$ ton $)$ to grey water, the volume of water needed to assimilate the nitrogen fertilisers that enter the water systems due to leaching or runoff.

The six big farms - Logonot Horticulture, Delamere, Oserian, Gordon-Miller, Marula Estate and Sher Agencies - account for about $56 \%$ of the total operational water footprint around Lake Naivasha (lower part of the catchment) and $60 \%$ of the blue water footprint related to crop production in the whole basin. 
Table 3 Water footprint per ton of crops grown around the lake, Period 1996-2005

\begin{tabular}{|c|c|c|c|c|}
\hline \multirow[t]{2}{*}{ Crops } & \multicolumn{4}{|c|}{ Average water footprint ( $\mathrm{m}^{3} /$ ton $)$} \\
\hline & Green & Blue & Grey & Total \\
\hline Flowers in greenhouse & 0 & 203 & 123 & 326 \\
\hline Flowers in open field & 210 & 102 & 123 & 435 \\
\hline Fodder & 279 & 240 & 34 & 553 \\
\hline Vegetable & 971 & 845 & 192 & 2009 \\
\hline Macadamia & 7705 & 8398 & 938 & 17041 \\
\hline
\end{tabular}

\subsection{The Water Footprint Per Cut Flower}

Depending on the yield and weight of a rose flower stem, the water footprint per stem varies from 7 to 13 litre/stem (Table 4). If we assume an average rose flower stem weights about 25 gram, its green water footprint would be 2 litre/stem, its blue water footprint 4 litre/stem and its grey water footprint 3 litre/stem, resulting in a total water footprint of 9 litre per stem.

\subsection{Virtual Water Export from the Lake Naivasha Basin}

When we assume that about $95 \%$ of Kenya's cut-flowers export comes from the area around Lake Naivasha, the average virtual water export from the Lake Naivasha Basin related to export of cut flowers was $16 \mathrm{Mm}^{3} / \mathrm{yr}$ in the period 1996-2005 (22\% green water, $45 \%$ blue water and $33 \%$ grey water) (Table 5). The European Union is Kenya's principal market for cut flowers; with the Netherlands, the UK, and Germany together taking over $90 \%$ of the virtual water export due to export of cut flowers. The Netherlands is the principal market, accounting for $69 \%$ of the total export, followed by the UK with $18 \%$ and Germany with $7 \%$. The virtual water export in relation to export of cut flowers has shown a significant growth, with virtual water export almost doubling from $11 \mathrm{Mm}^{3} / \mathrm{yr}$ in 1996 to $21 \mathrm{Mm}^{3} / \mathrm{yr}$ in 2005 .

In addition to cut flowers, vegetables such as beans, sweet corn, tomato, cabbage and onions are produced for both export and domestic consumption. About $50 \%$ of the vegetable produced around Lake Naivasha is exported and the remaining is supplied to local markets, mainly to Nairobi. The virtual water export related to vegetable products was $8.5 \mathrm{Mm}^{3} / \mathrm{yr}$. Most of the virtual water related to vegetable products was exported to the United Arab Emirates, France and the United Kingdom. Therefore, for the period 19962005 , the total virtual water export related to export of cut flowers and vegetable products was $24.5 \mathrm{Mm}^{3} / \mathrm{yr}$.

Table 4 The water footprint of a rose flower, Period 1996-2005

\begin{tabular}{lllllr}
\hline Weight of rose $(\mathrm{gram} / \mathrm{stem})$ & Cut flower production $\left(\mathrm{stem} / \mathrm{m}^{2}\right) *$ & \multicolumn{4}{l}{ Water footprint by type (litre/stem) } \\
\cline { 3 - 6 } & & Green & Blue & Grey & Total \\
\hline 20 & 134 & 1.6 & 3.3 & 2.5 & 7.3 \\
25 & 107 & 2.0 & 4.1 & 3.1 & 9.2 \\
35 & 77 & 2.8 & 5.8 & 4.3 & 12.8 \\
\hline
\end{tabular}

*with an average flower yield in Naivasha basin of 27 ton/ha 
Table 5 Major destinations of virtual water export related to export of cut flowers from the Lake Naivasha Basin, Period 1996-2005

\begin{tabular}{lllll}
\hline \multirow{2}{*}{ Country } & \multicolumn{4}{l}{ Virtual water export $\left(1,000 \mathrm{~m}^{3} / \mathrm{yr}\right)$} \\
\cline { 2 - 5 } & Green & Blue & Grey & Total \\
\hline Netherlands & 2399 & 4993 & 3708 & 11100 \\
United Kingdom & 611 & 1272 & 944 & 2827 \\
Germany & 230 & 478 & 355 & 1064 \\
Switzerland & 59 & 122 & 91 & 272 \\
South Africa & 37 & 77 & 57 & 171 \\
France & 33 & 68 & 51 & 152 \\
United Arab Emirates & 16 & 33 & 25 & 74 \\
Italy & 10 & 20 & 15 & 45 \\
Others & 64 & 133 & 98 & 295 \\
Total & 3458 & 7196 & 5345 & 16000 \\
\hline
\end{tabular}

The cut-flower industry is an important export sector, which contributed an annual average of US\$ 141 million foreign exchange ( $7 \%$ of Kenyan export value) over the period 1996-2005, and US\$ 352 million in 2005 alone. Hence, Kenya is generating foreign exchange of $(141 / 16=) 8.8 \mathrm{US} \$ \mathrm{~m}^{3}$.

Our estimate of virtual water export related to cut flower to the UK is more than 1.5 times larger than the estimate by Orr and Chapagain (2006). There are two major differences between the two studies which leads to different estimates in the virtual water export to the UK. Firstly, Orr and Chapagain (2006) have assumed an average cut flower yield of 66 ton/ ha while we have taken an average yield of $27 \mathrm{ton} / \mathrm{ha}$ which has led to large difference in the average water footprint $\left(\mathrm{m}^{3} /\right.$ ton $)$ of cut flower between the two studies. The yield value used by Orr and Chapagain (2006) is quite large compared to the range of values (17-34 ton/ha) provided by the HCDA (2008) and EPC (2004). Secondly, there is a difference in the quantity of cut flower export from Kenya to the UK in the two studies. While according to Orr and Chapagain (2006), the cut flower import by UK from Kenya is about 1,072 ton/yr, our trade data show a value of 8,759 ton/yr (ITC 2007).

\subsection{Sustainability of Water Use in the Lake Naivasha Basin}

The horticulture sector in Naivasha employs some 25,000 people directly and the same number of people is indirectly dependent, both as dependents and service providers (Becht et al. 2005). Most of the farms pay more than the legal minimum wage. The farms also provide housing, free medical services, schools for children of farm workers and social and sport facilities. Some of the larger farms also participate in the community development such as provision of clinic and ambulance services, water management and tree planting and watering of the community trees. A continued supply of freshwater to sustain the economy is a concern, however.

Lake Naivasha has been used for irrigation since the 1940s. Water is extracted directly from the lake, but also from groundwater and the rivers feeding the lake. Beside the irrigation water used for crop production, water from the basin is used for drinking water supply and since 1992 a pipeline became operational pumping 20,000 $\mathrm{m}^{3}$ per day from Malewa sub-basin to Gilgil and Nakuru Town (Becht and Nyaoro 2006; Musota 2008). The 
total water use for domestic purposes in the basin is estimated as $1.2 \mathrm{Mm}^{3} / \mathrm{yr}$. Altogether, the blue water footprint within the Lake Naivasha Basin is estimated to be $27 \mathrm{Mm}^{3} / \mathrm{yr}$ (Table 6).

The rainfall regime within the Lake Naivasha Basin is influenced by the rain shadow from the surrounding highlands of the Aberdare range to the east and the Mau Escarpment to the west. The long-term rainfall varies from about $600 \mathrm{~mm}$ at Naivasha town to some $1,700 \mathrm{~mm}$ on the slopes of the Nyandarua Mountains (Becht et al. 2005). Total basin rainfall and evapotranspiration are estimated at $2,790 \mathrm{Mm}^{3} / \mathrm{yr}$ and $2,573 \mathrm{Mm}^{3} / \mathrm{yr}$ respectively (Becht 2007). The annual runoff generated in the Lake Naivasha Basin is estimated at $217 \mathrm{Mm}^{3} / \mathrm{yr}$ (Becht and Harper 2002). The long-term average annual water balance of the basin is presented in Table 7.

Sustainability of the water footprint related to the production of horticultural and other crops, domestic and industrial water uses in Lake Naivasha Basin can be assessed by comparing the blue water footprint with the available blue water resources. The available blue water for human use is the difference between the annual runoff $(\mathrm{R})$ and the environmental flow requirements (EFR), which is set at $80 \%$ of runoff (Hoekstra et al. 2011). For the Lake Naivasha Basin the total blue water footprint is about $13 \%$ of the annual average runoff, which leaves $87 \%$ of the runoff for meeting environmental flow requirement. When we take the blue and grey water footprint together, they make $19 \%$ of the annual average runoff.

Comparing the blue-grey water footprint with the blue water available for human use at annual basis hides the seasonal variation, which is relevant particularly in basins with highly variable flow regimes (Hoekstra et al. 2012). Therefore, it is quite important to do the comparison on a monthly basis. The long-term average monthly runoff and environmental flow requirement and the monthly blue-grey water footprint within the Lake Naivasha Basin are presented in Fig. 1. The long-term average monthly runoff data for the basin for the period February 1932 to June 1981 was obtained from the ITC Naivasha database (Becht 2007). The monthly blue-grey water footprints were derived from the current study, taking into account the growth seasons of the various crops. In the dry period Jan-March, the blue plus grey water footprint is double the blue water availability, which means that twice the blue water availability is appropriated for either consumptive water use or assimilation of pollution. In November and December, the blue plus grey water footprint slightly exceeds the environmental flow requirement. There is no violation of the environmental flow requirements in the period April-October.

Table 6 The blue water footprint in the Lake Naivasha Basin

\begin{tabular}{|c|c|c|}
\hline & $\begin{array}{l}\text { Blue water footprint } \\
\left(\mathrm{Mm}^{3} / \mathrm{yr}\right)\end{array}$ & $\begin{array}{l}\text { Contribution to the total blue } \\
\text { water footprint }(\%)\end{array}$ \\
\hline Cut flower & 7.58 & 28 \\
\hline Vegetable and macadamia & 7.68 & 28 \\
\hline Grass and fodder & 3.19 & 12 \\
\hline Upper catchment crops & 0.47 & 2 \\
\hline Nakuru and Gilgil town ${ }^{1}$ & 7.30 & 27 \\
\hline Lake Naivasha Basin potable water ${ }^{2}$ & 1.19 & 4 \\
\hline Total & 27.4 & 100 \\
\hline
\end{tabular}

\footnotetext{
${ }^{1}$ Source: Becht and Nyaoro (2006); Musota (2008)

${ }^{2}$ the potable water use in the Lake Naivasha Basin is estimated based on a population of 650,000 , a per capita daily consumption of 50 litre and assuming a $90 \%$ return flow and $10 \%$ of the abstraction actually consumed
} 
Table 7 The long-term average annual water balance of Lake Naivasha Basin

\begin{tabular}{llr}
\hline & Basin water balance $\left(\mathrm{Mm}^{3} / \mathrm{yr}\right)$ & Fraction $(\%)$ \\
\hline Rainfall & 2790 & 100 \\
Evapotranspiration of rainwater from land & 2573 & 92.2 \\
Evapotranspiration from the lake & 256 & 9.2 \\
Groundwater outflow & 56 & 2.0 \\
Blue water footprint & 27 & 1.0 \\
Closing error & -122 & -4.4 \\
\hline
\end{tabular}

Source: Becht (2007); blue water footprint own calculation

A fluctuating lake level is a natural phenomenon for Lake Naivasha and a necessity for the functioning of the ecosystem. The climate, physical attributes and geographic context set the background for a hydrological cycle that results in natural lake level variability reaching above 12 meters over the last 100 years (Becht et al. 2005). However, Becht and Harper (2002) and Becht et al. (2005) show that the more recent decline in the lake level coincides with and can be explained by the commencement of horticulture crops in the area in 1982 (Fig. 2). Becht and Harper (2002) show that in late 1998, the lake was 3.5 meters lower than it would have been had it followed the hydrological records. On the other hand, according to Harper and Mavuti (2004), the current level of water abstraction has not led to a greater lake level fluctuation than as was recorded in the past, and there is no evidence that lake level fluctuations themselves risk biodiversity losses. Becht (2007) suggested that at a constant rate of water abstraction the lake will establish a new equilibrium lake level. He goes further by arguing that the question as to how much a drop in the lake level is acceptable is a societal and political one.

Although the recent reduction in the lake's water level can be attributed mainly to the commercial farms around the lake, the deterioration of the lake water quality as a result of the inflow of nutrients is due to both the commercial farms and the farm activities in the upper catchment. This finding is supported by Kitaka et al. (2002) and Gitachi (2005), who also showed that a large amount of nutrient load to the lake originates from the upper

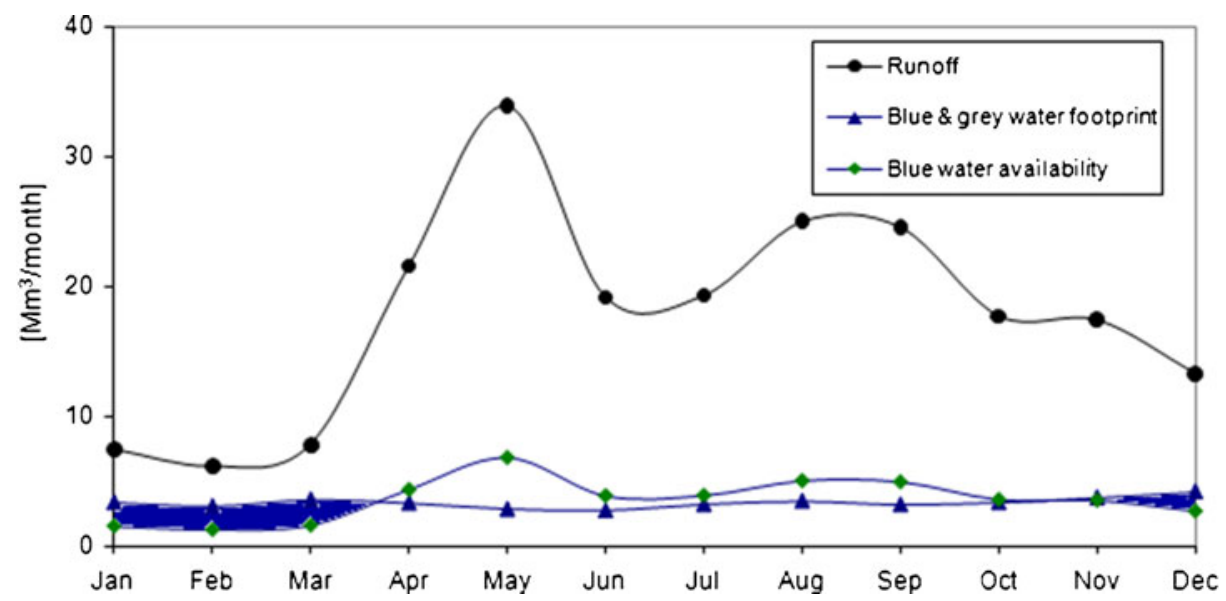

Fig. 1 Long term average monthly runoff, blue-grey water footprint and environmental flow of the Lake Naivasha Basin 


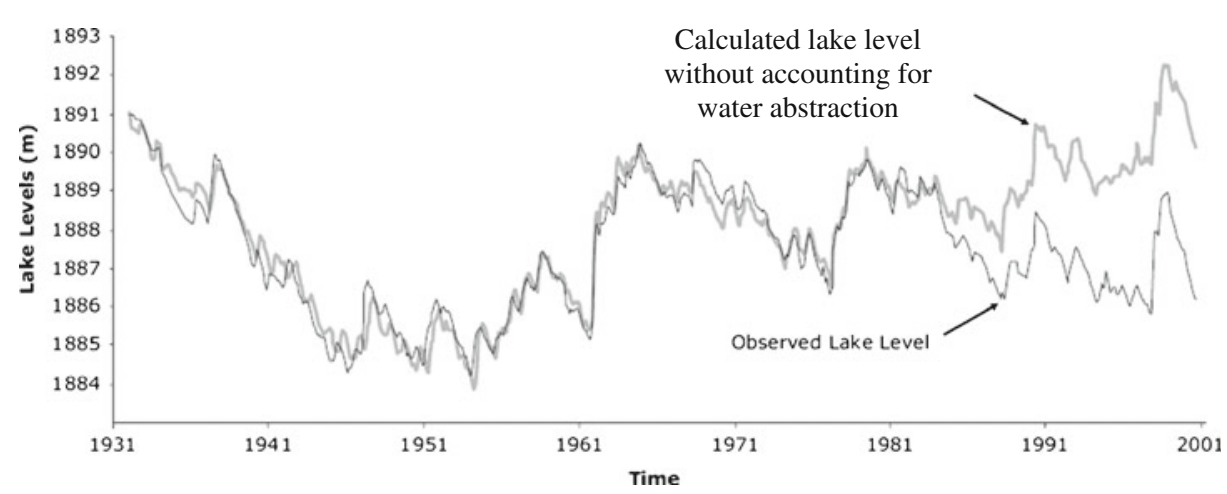

Fig. 2 Long-term water level change in Lake Naivasha. The calculated lake level represents the case without water abstraction (reproduced from Becht et al 2005)

catchments and municipal sewage through surface runoff. The nutrient transport from the upper catchments is mainly through surface runoff, while for the riparian agriculture nutrient transport is mainly through leaching to the groundwater.

There is a big and well-founded concern as to whether the lake can sustain a continued increase in irrigation water demand. The long-term protection of the lake ecosystem and the economic and social benefits that depend on the lake require a sustainable use of Lake Naivasha and its catchment. The most pressing issue is the unsustainable water abstraction for horticulture crops and domestic water use which has led to a decline in the lake level (Becht and Harper 2002). There is further the concern about eutrophication of the lake due to an increase in agricultural nutrients inflow both from the commercial farms and from the upper catchment. The increase in nutrients is probably the combined effect of the loss of riparian vegetation, which acts as a buffer to trap sediments, an increase in the sediment flow from the catchment and an increase in fertilisers leaching and running off to the water system. The situation got worse by the increase in subsistence farming even on steep slopes right down to the river edge which destroyed the riparian zone (Everard and Harper 2002).

There is a need to reduce the flow of sediments and agricultural nutrients to the lake both from the commercial farms around the lake and subsistence farmers in the upper catchment. The sedimentation problem is aggravated due to the loss of riparian vegetation that could have acted as a buffer in trapping sediments and increasing infiltration. An urgent and coordinated action is needed to stop the destruction of vegetation along the river banks and lake caused by cultivation and overgrazing. Therefore, prohibition of cultivation in the riparian areas is important.

Long-term gains from a sustainable and wise use of water require a coordinated action at the catchment scale. There is a need to define the maximum allowable water abstraction level at the basin scale. Although equitable allocation of water is required, decisions should also take into account the difference in economic water productivity among different crops. Cut flowers generate more economic return than the low-value fodder crops and grasses. Indoor flowers are more efficient compared to outdoor flowers; therefore greenhouse cultivation should be encouraged. The use of blue water for the production of water-intensive products such as beans and low-value products such as grass and fodder should be discouraged. Wise use of rainwater, in particular in the upper catchment, for growing fodder and grass needs to be encouraged. Controlling of unlicensed and illegal water abstraction through legal means and community involvement is quite essential. 


\section{Reducing the Water Footprint in the Lake Naivasha Basin: Involving Consumers, Retailers and Traders along the Supply Chain}

\subsection{Current Water Regulations in the Lake Naivasha Basin}

Lack of funding is one of the main challenges in the Lake Naivasha Basin for implementing community-based basin rehabilitation and lake conservation (Becht et al. 2005). Under such condition, raising enough funds would be an additional objective of water pricing, besides creation of an incentive for efficient and sustainable use of water. However, the implementation of full marginal-cost pricing under the existing conditions in Kenya and around Naivasha is highly unlikely. The flower farms feel that they are already overtaxed and burdened with a number of remittances and some even have threatened to relocate to Ethiopia if local authorities force them to pay more tax (Riungu 2007). Attracted by a number of incentives including 10 year tax-holidays, better security, duty-free import of capital goods and low land price, five major flower companies have already made the switch to Ethiopia with more to follow (ARB 2007).

According to the 2007 Water Resource Management Rules, domestic water users have to pay 0.50 Kenyan Shilling per $\mathrm{m}^{3}$ and non-domestic water users have to pay 0.50 to 0.75 Kenyan Shilling per $\mathrm{m}^{3}$. Major water users need a license to abstract water and need to install water meters. Implementation of the regulation is actually hampered, however, by reluctance of many water users to follow the regulation and difficulties government encounters in enforcing the regulation. The current water pricing policy has several weaknesses. One is that illegal water abstractions from both ground- and surface water are very common. In practice it is difficult for the government to check whether farmers, particularly in the upper catchment, have actually installed water meters as legally required, due to a lack of cars and fuel for the staff responsible for control. Despite the fact that farmers have indicated that the newly introduced water tariff is too high, the tariff actually does by far not cover full economic cost of the water. As a result, the funds generated by the current water pricing scheme are very small. The level of water price increase that would be required to have a significant impact on demand would be politically very difficult to enforce.

Under such conditions, the implementation of full-cost water pricing at the source is not feasible. A unilateral implementation of a stringent water pricing strategy by a country could affect the competitiveness of its local companies in the global market (Hoekstra 2011; Cornish et al. 2004). To address this problem, Hoekstra (2011) has proposed that national governments negotiate on an international protocol on water pricing. Such scheme would reduce the disadvantage of unilateral implementation of a full-cost pricing strategy. However, the implementation of an international protocol on water pricing requires global agreement among the major players on the global market, which makes it unlikely that such a protocol will be implemented in the near future. As an alternative to the international protocol involving national governments we propose an alternative here that can be implemented with a focus on sustainable water use in flower farming around Lake Naivasha alone. The proposal involves a watersustainability agreement between major agents along the cut-flower supply chain and includes a premium to the final product at the retailer end of the supply chain.

5.2 A Sustainable-Flower Agreement between Major Agents along the Cut-Flower SupplyChain

Given the recent emergence of more environmentally conscious consumers, combined with an increased interest at the side of traders and retailers in providing environmentally 
sustainable consumer products, involving consumers and other stakeholders forms an opportunity to achieve sustainable water use in cut-flower production. Consumers are becoming more and more concerned with how their consumption behaviour is affecting the world around them. This is reflected in the growing consumption of fair-trade products and organic produce. Annual growth rates of $20 \%$ or more in market volume have been observed for many years for both organic and fair-trade products (Poisot et al. 2007; Krier 2005). Several studies show that consumers are willing to pay more for products that are environmentally and socially responsible (Aizaki and Sato 2007; Arnot et al. 2006; Didier and Lucie 2008; Pelsmacker et al. 2005).

In this section we describe the possible characteristics of a 'sustainable-flower agreement' between major agents along the flower supply-chain focused on sustainable water use. The agreement should include two key ingredients: a fund-raising mechanism at the consumerend of the supply chain, which will raise the funds for making water use in flower production sustainable, and a labelling or certification scheme, which will provide the guarantee that the funds are properly spent and that the flower production actually moves in the direction of sustainable water use.

Funds The premium collected when selling cut flowers from the Lake Naivasha Basin to consumers in the Netherlands, the UK etc. should be used to invest in better watershed management and, most in particular, in reducing the water footprint of the flower farmers. Clear criteria need to be formulated for how collected funds can or should be spent. The criteria could be formulated such that also small farmers belong to the beneficiaries of the funds, because particularly smallholder farmers have generally more difficulty than the large farmers to comply with environmental standards or raise funds to be able to comply.

There is a need to provide institutional infrastructure through which the funds could flow back to the basin and be used in environmental protection, watershed management, support of farmers to improve their water management and community development. Fair-trade organisations can be instrumental in making sure that funds raised at the consumer end flow back to the watershed for the support of local programmes for improved watershed management and support to farmers to reduce their water footprint. Figure 3 is a visual representation of the cut-flower supply chain and contrasts the current approach of local water pricing with the approach of collecting a water-sustainability premium at the end of the chain.

The funds that can be raised through adding a water-sustainability premium at the end of the supply chain (at the consumer end) are much larger than the funds potentially raised from



Fig. 3 Schematization of the flower supply-chain. Local water pricing is a mechanism applied at the beginning of the chain; a water-sustainability premium is raised at the end of the chain. Due to the increase of the price per flower along the supply-chain, generating funds is easier at the end of the chain 
the current local water-pricing policy. Currently, the water abstraction fee in Kenya for commercial farmers is 0.50 Kenyan Shillings per cubic meter of water abstracted $(0.007 € /$ $\mathrm{m}^{3}$ ). The total water abstraction by the commercial farms around the lake is estimated at $40 \mathrm{Mm}^{3} / \mathrm{yr}$ and out of this the flower farms receive about $50 \%$ (Becht 2007). With a water abstraction fee of $0.007 € / \mathrm{m}^{3}$, this would raise 0.13 million $€ / y$ r. Given an annual cut-flower export of 1.7 billion stems, they will thus pay, on average, $0.000076 €$ per stem of cut flower for abstracting irrigation water. This is a very optimistic estimate, because as explained before, the conditions are not such that government is actually able to enforce farmers to pay. On the other hand, if we assume a water sustainability premium of $0.01 €$ per stem of cut flower at the retailer, to be paid by the consumer, one would raise 16.9 million $€ / y r$. When we look at the capability of generating funds for watershed management, we find that a water-sustainability premium raised at the consumer end of the supply-chain will yield hundred to two hundred times the amount of money potentially raised through local water pricing. Implementing the water-sustainability premium will benefit all stakeholders inside the basin at a very small cost to the consumer, The major challenge, however, will be setting up institutional arrangements that make the flow of funds from flower consumers to improved management around Lake Naivasha actually happen.

Certification/Labelling Collecting a water-sustainability premium at the lower end of the supply chain needs to go hand in hand with a mechanism for certification of the farmers that deliver the premium-flowers and a mechanism for labelling the premium-flowers. Labelling can be interpreted here in physical sense-where indeed a consumer-oriented label is attached to a flower - but it can also get the shape of 'attached information' to whole batches of flowers. Customers can be encouraged to buy flowers from certified farms or labelled flowers and pay an agreed premium to contribute to the sustainability of production and consumption. Certification and labelling would help to segregate environmentally sustainable products from other products and provide consumers with the quality assurance. The success depends on a transparent, credible monitoring and certification systems. Farmers would benefit by having an advantage on the market by achieving standards of production that are internationally recognized. Lessons can be gained from the experience of the Forest Stewardship Council in setting standards and certification of forest products (FSC 2002).

The certification of farmers and labelling of products could be carried out by the already existing institutional setup of Global Good Agricultural Practices (GlobalGAP). The watersustainability standards can possibly be integrated into the existing standards of GlobalGAP. GAP is already applied in many developed and developing countries including Kenya. Farmers who have complied with the GlobalGAP have benefited in the form of increased access to market, increased productivity and reduced cost of production through careful application of pesticide and fertilizer.

The approach sketched here would encourage flower farmers to comply with criteria on sustainable use of water resources. The costs involved in certification and labelling should be covered by the funds raised, but should be small relative to the funds raised, since the funds are primarily meant to promote sustainable water use within the catchment. This is a serious concern when implementing a water-sustainability agreement, because when costs become too high the instrument looses its effectiveness.

Parties Involved in the Agreement In its most modest form, a water-sustainability agreement would involve one major retailer in the Netherlands (the most important destination country for Kenyan flowers), one trader and one of the major farmers. In a more ambitious setting, 
several retailers, traders and farmers could be involved. Retailers, traders or farmers could also be represented by their respective branch organisations. In the case of the flower farmers this could be the Lake Naivasha Growers Group or the Kenyan Flower Council. In the Netherlands, the flower market is organised by FloraHolland, which may take a central role in facilitating an agreement.

Apart from the funds raised to reduce the water footprint in the Lake Naivasha basin, an additional advantage of a water sustainability premium to the final consumer product at the retailer is that it helps to create awareness regarding the value of water along the supply chain down to the consumers. An advantage of raising funds at the consumer end over local full-cost water pricing is that the latter would reduce local competitiveness and diminish profitability. This may lead to a shift of flower farming out of Kenya to other countries, like Ethiopia, which currently experiences a growth in the horticulture sector.

Success of the water-sustainability premium depends on all stakeholders' commitment to reach agreement and effectively implement it. Further, a clearly defined certification procedure and institutional arrangements for the flow of fund back to the basin is required. Finally, costs of implementation need to be kept low enough to make the scheme feasible and costeffective.

\section{Discussion}

Cut flowers are an important export sector in Kenya. Next to their contribution to the gross domestic product and foreign exchange earnings, the commercial farms provide employment, housing, schools and hospitals, free to employees and their families. Losing the cutflower business means over 25,000 workers and their dependence will lose everything. On the other hand, the treatment of Lake Naivasha as a free 'common pool' resource will be at the cost of the lake's sustainability and the corporate image of the commercial farms. Therefore, sustainable management of the water resources of the Lake Naivasha Basin is needed. One will need to decide on the maximum allowable drop in the lake water level as a result of water abstractions and on the maximum allowable blue and grey water footprint in the basin. The use of greenhouse flower production (as opposed to production in the open field) needs to be encouraged. The production of water-intensive products such as beans and low-value products such as fodder and grass around the lake should be discouraged. In the upper catchment, the use of rainwater for the production of fodder and grass should be promoted. The flow of sediments and agricultural nutrients to the lake, both from commercial farms around the lake and farms in the upper catchment, needs to be reduced. The flow of sediment is aggravated due to the loss of riparian vegetation that could have acted as a buffer in trapping sediments. Therefore it is important to create awareness among farmers to protect the riparian zone vegetation and prohibit cultivation in the riparian area.

Pricing water at its full marginal cost is important, but probably difficult to achieve under current and near-future conditions in Kenya. The alternative of a water sustainability premium to flowers sold at the retailer may be more effective. It will generate a larger fund than local water pricing, a fund that can be used for financing improved watershed management and measures that reduce the blue and grey water footprint within the Lake Naivasha Basin. Besides, it would create awareness among consumers on the value of water. The mechanism of a water-sustainability premium will reduce the risk of Kenya losing its business in the long term. An added value of the water-sustainability premium includes the aspect of fairness, since currently the overseas consumers of cut flowers get the benefit but 
do not cover the environmental cost of the flowers. The mechanism can enhance the green image of the commercial farms and increase chances in the market for sustainable products. Successful implementation of the water-sustainability premium to cut flowers sold by the retailer depends on the commitment of all stakeholders: governments, civil society organizations, private companies and consumers.

Open Access This article is distributed under the terms of the Creative Commons Attribution License which permits any use, distribution, and reproduction in any medium, provided the original author(s) and the source are credited.

\section{References}

Aizaki H, Sato N (2007) Consumers' valuation of good agricultural practice by using contingent valuation and contingent ranking methods: a case study of Miyagi Prefecture, Japan. Agr Inform Res 16(3):150-157

ARB (2007) Flowers: Kenya. Af Res Bull 43(11):17197A-17198A

Ariga J, Jayne TS, Nyoro J (2006) Factors driving the growth in fertilizer consumption in Kenya, 1990-2005: sustaining the momentum in Kenya and lessons for broader replicability in Sub-Saharan Africa, Tegemeo Working paper 24/2006. Nairobi, Kenya

Arnot C, Boxall PC, Cash SB (2006) Do ethical consumers care about price? A revealed preference analysis of fair trade coffee purchases. Can J Agr Econ 54:555-565

Baille M, Baille A, Delmon D (1994) Microclimate and transpiration of greenhouse rose crops. Agr Forest Meteorol 71:83-97

Batjes NH (2006) ISRIC-WISE derived soil properties on a 5 by 5 arc-minutes global grid. Report 2006/02, ISRIC-World Soil Information, Wageningen, The Netherlands, www.isric.org. Accessed June 28, 2010

Becht R (2007) Environmental effects of the floricultural industry on the Lake Naivasha basin, unpublished paper, ITC Naivasha Database, Enschede, The Netherlands

Becht R, Harper DM (2002) Towards an understanding of human impact upon the hydrology of Lake Naivasha, Kenya. Hydrobiologia 488:1-11

Becht R, Nyaoro JR (2006) The influence of groundwater on lake-water management: the Naivasha case. In: Odada EO (ed) Proceedings of the 11th world lakes conference, 31 October-4 November 2005, vol II. Ministry of Water and Irrigation; International Lake Environment Committee, Nairobi, Kenya, pp 384-388

Becht R, Odada O, Higgins S (2005) Lake Naivasha: experience and lessons learned brief. In: ILEC, 2005, Managing lakes and their basins for sustainable use: a report for lake-basin managers and stakeholders. International Lake Environment Committee Foundation, Kusatsu, Japan

Chapagain AK, Hoekstra AY (2004) Water footprints of nations, Value of Water Research Report Series No. 16, UNESCO-IHE, Delft, The Netherlands

Cornish G, Bosworth B, Perry C, Burke J (2004) Water Charging in Irrigated Agriculture: an Analysis of International Experience, FAO Waters Reports 28. FAO, Rome, Italy

de Pelsmacker P, Driesen L, Rayp G (2005) Do consumers care about ethics? Willingness to pay for fair-trade coffee. J Consum Aff 39(2):369-385

Didier T, Lucie S (2008) Measuring consumer's willingness to pay for organic and fair trade products. Int J Consum Stud 32(5):479-490

Dinar A, Subramanian A (1998) Policy implications from water pricing experiences in various countries. Water Pol 1(2):239-250

EPC (2004) south-south trade promotion programme: Kenya supply survey on horticultural products. The Export Promotion Council Nairobi, Kenya

EPZA (2005a) Grain production in Kenya. Export Processing Zones Authority, Nairobi, Kenya

EPZA (2005b) Horticulture industry in Kenya. Export Processing Zones Authority, Nairobi, Kenya

Everard M, Harper DM (2002) Towards the sustainability of the Lake Naivasha Ramsar site and its catchment. Hydrobiologia 488:191-202 
FAO (2005) “Kenya Country Report.” In: Irrigation in Africa in Figures, AQUASTAT Survey 2005, Food and Agriculture Organization Rome, Italy. www.fao.org/nr/water/aquastat/countries/kenya/index.stm, Accessed June 28, 2010

FAO (2007a) CROPWAT model, Food and Agriculture Organization, Rome, Italy. www.fao.org/nr/water/ infores_databases_cropwat.html, Accessed June 28, 2010

FAO (2007) $\bar{b}$ ) CLIMWAT database, Food and Agriculture Organization, Rome, Italy, www.fao.org/nr/water/ infores databases climwat.html, Accessed June 28, 2010

FAO (2007) $)$ FAOSTAT on-line database, Food and Agriculture Organization, Rome, Italy http:// faostat.fao.org, Accessed June 28, 2010

FAO (2008) Global map of monthly reference evapotranspiration - 10 arc minutes. GeoNetwork: grid database, http:// www.fao.org/geonetwork/srv/en/resources.get?id=7416\&fname=ref_evap_fao_10min.zip\&access=private, Accessed June 28, 2010

FAO (2009) FertiStat - Fertilizer use statistics. http://www.fao.org/ag/agl/fertistat/, Accessed June 28, 2010

FSC (2002) FSC principles and criteria for forest stewardship, Forest Stewardship Council (FSC), Bonn, Germany, http://www.fsc.org/fileadmin/web-data/public/document center/international FSC policies/ standards/FSC STD 01001 V4 0 EN FSC Principles and Criteria.pdf

Gitachi S (2005) Lake Naivasha: a case study in IW̄RM in Kenya, www.netwas.org/newsletter/articles/2005/ 01/7, Accessed September 5, 2008

Harper D, Mavuti K (2004) Lake Naivasha, Kenya: ecohydrology to guide the management of a tropical protected area. Ecohydrol Hydrobiol 4(3):287-305

HCDA (2007) Horticulture products export volume statistics, Horticultural Crops Development Authority Nairobi, Kenya, www.hcda.or.ke/default2.asp?active_page_id=92, Accessed August 9, 2007

HCDA (2008) Horticulture data 2005-2007 validation report, Horticultural Crops Development Authority, Nairobi, Kenya, http://www.kilimo.go.ke/kilimo docs/pdf/horticulture report.pdf

Hoekstra AY (2011) The global dimension of water governance: why the river basin approach is no longer sufficient and why cooperative action at global level is needed. Water12 3(1):21-46

Hoekstra AY, Chapagain AK (2007) Water footprints of nations: water use by people as a function of their consumption pattern. Water Resour Manag 21(1):35-48

Hoekstra AY, Chapagain AK (2008) Globalization of water: sharing the planet's freshwater resources. Blackwell Publishing, Oxford, UK

Hoekstra AY, Chapagain AK, Aldaya MM, Mekonnen MM (2011) The water footprint assessment manual: setting the global standard. Earthscan, London, UK

Hoekstra AY, Mekonnen MM, Chapagain AK, Mathews RE, Richter BD (2012) Global monthly water scarcity: blue water footprints versus blue water availability. PLoS One 7(2):e32688. doi:10.1371/ journal.pone. 0032688

ITC (2007) SITA version 1996-2005 in SITC, [DVD-ROM]. International Trade Centre, Geneva

Kisima (2007) Will SWAps fix the water sector? Kisima Issue 4 January 2007

Kitaka N, Harper DM, Mavuti KM (2002) Phosphorus inputs to Lake Naivasha, Kenya, from its catchments and the trophic state of the lake. Hydrobiologia 488:73-80

Krier, Jean-Marie (2005) Fair trade in Europe 2005: Facts and figures on fair trade in 25 European countries. www.fairtrade.net/fileadmin/user upload/content/FairTradeinEurope2005.pdf, Accessed June 28, 2010

Mavuti KM, Harper DM (2005) The ecological state of Lake Naivasha, Kenya, 2005: Turning 25 years research into an effective Ramsar monitoring programme, www.oceandocs.org/bitstream/1834/2127/1/ WLCK-30-34.pdf, Accessed 25 Sept., 2008

Mekonnen MM, Hoekstra AY (2010) A global and high-resolution assessment of the green, blue and grey water footprint of wheat. Hydrol Earth Syst Sci 14(7):1259-1276

Mitchell TD, Jones PD (2005) An improved method of constructing a database of monthly climate observations and associated high-resolution grids. International Journal of Climatology, 25, 693-712. http:// cru.csi.cgiar.org/continent_selection.asp, Accessed October 3, 2008

Molle F, Berkoff $\mathbf{J}$ (2007) Water pricing in irrigation: the lifetime of an idea. In: Molle F, Berkoff J (eds) Irrigation water pricing: the gap between theory and practice, comprehensive assessment of water management in agriculture series no. 4. CAB International Publication, Wallingford, UK and Cambridge MA, USA, pp 1-20

Monfreda C, Ramankutty N, Foley JA (2008) Farming the planet: 2. Geographic distribution of crop areas, yields, physiological types, and net primary production in the year 2000, Global Biogeochemical Cycles, Vol.22, GB1022, doi:10.1029/2007GB002947. www.geog.mcgill.ca/landuse/pub/Data/175crops2000, Accessed Jun 28, 2010

Mpusia PTO (2006) Comparison of water consumption between greenhouse and outdoor cultivation, M.Sc. Thesis, ITC, Enschede, The Netherlands 
Mumma A (2005) Kenya's new water law: An analysis of the implications for the rural poor. Paper presented at the international workshop on "African water laws: Plural legislative frameworks for rural water management in Africa", Johannesburg, January 26-28, 2005

Musota R (2008) Using WEAP and scenarios to assess sustainability of water resources in a basin. Case study for Lake Naivasha catchment-Kenya, M.Sc. Thesis, ITC, Enschede, The Netherlands

Orgaz F, Fernández MD, Bonachela S, Gallardo M, Fereres E (2005) Evapotranspiration of horticultural crops in an unheated plastic greenhouse. Agr Water Manag 72:81-96

Orr S, Chapagain A (2006) Virtual water: a case study of green beans and flowers exported to the UK from Africa, Fresh Insights No. 3, www.agrifoodstandards.net/en/filemanager/active?fid=67, Accessed Jun 28, 2010

Owuor SO, Foeken DWJ (2009) Water reforms and interventions in urban Kenya : Institutional set-up, emerging impact and challenges, African Studies Centre Working Paper 83, Leiden, The Netherlands

Perry C (2003) Water pricing: some important definitions and assumptions, Occasional Paper No. 59, SOAS Water Issues Study Group, University of London, www.soas.ac.uk/waterissues/papers/file38402.pdf, Accessed Jun 28, 2010

Poisot AS, Speedy A, Kueneman E (2007) Good agricultural practices - a working concept: background paper for the FAO Internal workshop on good agricultural practices, FAO GAP working paper series 5. Food and Agriculture Organization, Rome, Italy

Portmann F, Siebert S, Bauer C, Döll P (2008) Global data set of monthly growing areas of 26 irrigated crops. Frankfurt Hydrology Paper 06, Institute of Physical Geography, University of Frankfurt, Frankfurt am Main, Germany, www.geo.uni-frankfurt.de/ipg/ag/dl/f_publikationen/2008/FHP_06_Portmann_et_al_2008.pdf, Accessed Jun 28, 2010

Riungu C (2007) Kenya: Naivasha flower farms win first round in tax war, http://allafrica.com/stories/ 200708140634.html, Accessed Jun 28, 2010

Rogers P, de Silva R, Bhatia R (2002) Water is an economic good: how to use prices to promote equity, efficiency and sustainability. Water Pol 4(1):1-17

Rosegrant MW, Cline S (2002) The politics and economics of water pricing in developing countries. Water Resources Impact 4(1):6-8

Schuol J, Abbaspour KC (2007) Using monthly weather statistics to generate daily data in a SWAT model application to West Africa. Ecol Model 201:301-311

Siebert S, Döll P, Feick S, Hoogeveen J, Frenken K (2007) Global map of irrigation areas version 4.0.1. Johann Wolfgang Goethe University, Frankfurt am Main, Germany / Food and Agriculture Organization of the United Nations, Rome, Italy, http:/www.fao.org/nr/water/aquastat/irrigationmap/index10.stm, Accessed Jun 28, 2010

Tiruneh BA (2004) Modelling water quality using soil and water assessment tool SWAT : a case study in Lake Naivasha basin, Kenya. M.Sc. Thesis, ITC, Enschede, The Netherlands

UN (1992) Agenda 21: The United Nations programme of action from Rio, United Nations, New York, USA

World Bank (2004) World Bank Water Resources Sector Strategy: Strategic Directions for World Bank Engagement, World Bank, Washington, DC, USA

World Water Commission (2000) A water secure world: Vision for water, life, and the environment, world water vision commission report. World Water Commission, The Hague, The Netherlands

Xu TZ (1999) Water quality assessment and pesticide fate modelling in the Lake Naivasha area, Kenya. M.Sc. Thesis, ITC, Enschede, The Netherlands 